\title{
Lantana camara L.: a weed with great light-acclimation capacity
}

\author{
J. CARRIÓN-TACURI ${ }^{+}$, A.E. RUBIO-CASAL, A. de CIRES, M.E. FIGUEROA, and J.M. CASTILLO \\ Departamento de Biología Vegetal y Ecología, Universidad de Sevilla, Ap. 1095, 41080 Sevilla, Spain
}

\begin{abstract}
Plant invasions may be limited by low radiation levels in ecosystems such as forests. Lantana camara has been classified among the world's 10 worst weeds since it is invading many different habitats all around the planet. Morphological and physiological responses to different light fluxes were analyzed. $L$. camara was able to acclimate to moderately shaded environments, showing a high phenotypic plasticity. Morphological acclimation to low light fluxes was typified by increasing leaf size, leaf biomass, leaf area index and plant height and by reduced stomatal density and leaf thickness. Plants in full sunlight produced many more inflorescences than in shaded conditions. Physiological acclimation to low radiation levels was shown to be higher stomatal conductance, higher net photosynthetic rates and higher efficiency of photosystem II (PSII). L. camara behaves as a facultative shade-tolerant plant, being able to grow in moderately sheltered environments, however its invasion could be limited in very shady habitats. Control efforts in patchy environments should be mainly directed against individuals in open areas since that is where the production of seeds would be higher and the progress of the invasion would be faster.
\end{abstract}

Additional key words: chlorophyll fluorescence; gas exchange; leaf growth rate; light acclimation; photosynthetic pigments; trade-off.

\section{Introduction}

Several features of plant form, physiology, and resource allocation vary with the level of irradiance to which plants are acclimated and/or ecologically restricted (Givnish 1988); thus, plants exposed to high irradiance levels generally have higher photosynthetic rates, chlorophyll (Chl) $a / b$ ratio, leaf thickness, stomatal density and reproductive efforts, and smaller stomatal size than plants at low light conditions (Boardman 1977, Björkman 1981, Bazzaz et al. 1987, Givnish 1987).

Leaf morphology and anatomy, gas exchange, water relations, water-use efficiency, stomatal conductance $\left(g_{\mathrm{s}}\right)$, biomass and photosynthesis of sun-adapted plants can be altered when growing in a light-limiting environment (Björkman 1981, Muthuchelian et al. 1989). In addition, shade diminishes reproductive potential directly by decreasing flowering, fruit set and fruit size (Hampson et al.1996). To avoid negative effects of low radiation levels, some plants show a high degree of phenotypic plasticity in response to low light conditions, manifested in increased leaf area and stem biomass, reduced leaf thickness, increased specific leaf area and increased photosynthetic pigment concentration for maximization of light absorption (Björkman 1981, Turnbull 1991, Poorter and Perez-Soba 2001, Sage and McKown 2006).

Invasive plant species may show a high tolerance to different abiotic environmental factors (Mack 1996) but their colonization may be limited by extreme conditions such as low radiation levels (Dawson et al. 2009). In this context, the tolerance of invasive species to harsh environments may be related to rapid evolutionary changes (Lambrinos 2004) and high phenotypic plasticity (Daehler 2003).

L. camara L. (Verbenaceae) has been classified among the world's 10 worst weeds, invading a wide variety of habitats in tropical, subtropical and temperate regions (Holm et al. 1977, Sharma et al. 1988, Day et al. 2003).

Received 16 December 2010, accepted 12 May 2011.

${ }^{+}$Corresponding author; tel.: +34-954557433, e-mail: jorgecarrion@us.es

Abbreviations: $C_{\mathrm{i}}$ - intercellular $\mathrm{CO}_{2}$ concentration; $\mathrm{Car}$ - carotenoids; $\mathrm{Chl}$ - chlorophyll; $\mathrm{F}_{\mathrm{m}}$ - maximal fluorescence level in the dark-adapted state; $\mathrm{F}_{0}-$ minimal fluorescence level in the dark-adapted state; $\mathrm{F}_{\mathrm{v}} / \mathrm{F}_{\mathrm{m}}-$ maximum quantum efficiency of PSII photochemistry; $g_{s}$ - stomatal conductance; LAI - leaf area index; LCP - light compensation point; LGR - leaf growth rate; LSP - light saturation point; NPQ - nonphotochemical quenching; $P_{\max }-$ maximum photosynthetic rate; $P_{\mathrm{N}}-$ net photosynthetic rate; PPFD - photosynthetic photon flux density; PSII - photosystem II; $\mathrm{q}_{\mathrm{P}}$ - photochemical quenching; $R_{\mathrm{D}}$ - dark respiration rate; SLA - specific leaf area; $W_{U E}$ - intrinsic water-use efficiency; $\Phi_{\text {PSII }}-$ quantum efficiency of PSII.

Acknowledgements: This research is supported by "Agencia Española de Cooperación Internacional para el Desarrollo" (AECID) through a grant to the first author. Thanks to Juan Luis Ribas, Guillermo Curado, Aida Arroyo and Ahmed Mahmoud Abbas for their assistance. 
Researchers have described L. camara as mostly occupying open sunny places such as degraded lands, grasslands, crops and forest edges, abandoned crops, coastal areas or disturbed forests (Parsons and Cuthbertson 2001, Sharma et al. 2005), and as not developing properly in very shady habitats such as wellconserved forests (Thakur et al. 1992, Fensham et al. 1994, Gentle and Duggin 1997). However, our field observations of invasive populations of L. camara in the Galapagos Islands and in the Southwest Iberian Peninsula showed that they were able to grow in unaltered forests.

\section{Materials and methods}

Plant material and light treatments: Plant material was collected in May 2009, consisting in stem cuttings of ten adult individuals of $L$. camara (4 cuttings per individual) collected from an invading population growing at an open, unshaded site on the Asperillo Sea Cliff, Southwest Iberian Peninsula $\left(37^{\circ} 06^{\prime} \mathrm{N}-6^{\circ} 46^{\prime} \mathrm{W}\right)$. Cuttings with similar sizes ( $c a .20 \mathrm{~cm}$ long and $c a .1 \mathrm{~cm}$ diameter) were cultivated in perlite substrate until they developed abundant roots and then were transplanted to plastic pots (diameter: $16.5 \mathrm{~cm}$; depth: $15.0 \mathrm{~cm}$ ) in peat soil and immediately exposed to the light treatments. Every pot contained just one cutting that was chosen randomly from those collected in the field.

Our experiment was conducted in the open-air area of the greenhouse facilities of the University of Seville $\left(37^{\circ} 21^{\prime} 42^{\prime \prime} \mathrm{N}-5^{\circ} 59^{\prime} 15^{\prime \prime} \mathrm{W}\right)$ from July to December 2009. Pots were randomly assigned to one of four light treatments: (T1): $100 \%$ of full sunlight, (T2): $55 \%$ of full sunlight, (T3): $37 \%$ of full sunlight and (T4): $23 \%$ of full sunlight $(n=4$ plants per treatment). Irradiance was controlled with neutral shade cloth (Hummert International, Earth City, MO USA). Although deep shade $(<5 \%)$ is traditionally used in shade-tolerance studies, we used $23 \%$ of full sunlight because it represents the deepest shade generally found in the natural forests of Galapagos Island and coastal areas of Southwest Iberian Peninsula where L. camara is invading (Carrión-Tacuri, unpublished data). Maximum daily photosynthetic photon flux density (PPFD) during the experiment ranged from $1,900 \mu \mathrm{mol}$ (photon) $\mathrm{m}^{-2} \mathrm{~s}^{-1}$ in July to $1,100 \mu \mathrm{mol}$ (photon) $\mathrm{m}^{-2} \mathrm{~s}^{-1}$ in December. Pots were permanently submerged $1 \mathrm{~cm}$ deep in water and watered gently once a day to avoid water stress.

Gas-exchange measurements were taken for the youngest fully developed leaf of randomly chosen stems using an infrared gas analyzer in an open system (LI-6400, Li-COR Inc., Lincoln, NE, USA). Net photosynthetic rate $\left(P_{\mathrm{N}}\right)$, stomatal conductance $\left(g_{\mathrm{s}}\right)$ and intercellular $\mathrm{CO}_{2}$ concentration $\left(C_{\mathrm{i}}\right)$ were recorded in October 2009 within light saturation curves $(n=2$ curves per treatment, Martínez-Ferri et al. 2004). Measurements were taken at $23^{\circ} \mathrm{C}, 380 \mu \mathrm{mol} \mathrm{mol}{ }^{-1}$ of $\mathrm{CO}_{2}$ concen-
There has been no prior research specifically studying the responses of $L$. camara to different radiation environments.

Our observations in the field led us to hypothesize that $L$. camara would be able to grow in shady environments, showing high phenotypic plasticity in response to different light environments. To test this hypothesis, this work analyzes a series of morphological and physiological responses of $L$. camara to four contrasted light fluxes.

tration. Vapour pressure deficit (VPD) was held at a constant range from $1-1.3 \mathrm{kPa} . P_{\mathrm{N}}, g_{\mathrm{s}}$, and $C_{\mathrm{i}}$ were calculated according to von Caemmerer and Farquhar (1981). Intrinsic water-use efficiency $\left(\mathrm{WUE}_{\mathrm{i}}\right)$ was calculated as the ratio between $P_{\mathrm{N}}$ and $g_{\mathrm{s}}$ (Moutinho-Pereira et al. 2004). The photosynthetic response of the leaves to photosynthetic photon flux density (PPFD) was modelled by a rectangular hyperbola quadratic equation presented by Chartier and Prioul (1976), where the light compensation point (LCP) and the dark respiration rate $\left(R_{\mathrm{D}}\right)$ were estimated from axis intercepts. The light saturation point (LSP) was defined as the lowest value of PPFD at which maximum photosynthetic rate $\left(P_{\max }\right)$ was reached.

Chl $\boldsymbol{a}$ fluorescence parameters were also recorded in October 2009 at predawn and at midday at the light flux of each treatment. Measurements were taken at $23^{\circ} \mathrm{C}$ air temperature with $62 \%$ air relative humidity at predawn and at $24^{\circ} \mathrm{C}$ with $58 \%$ humidity at midday.

Fluorescence was measured in the adaxial leaf surface of the youngest fully developed leaf of randomly chosen stems ( $n=4$ plants per treatment; 4 leaves per plant) using a portable modulated fluorimeter (FMS-2, Hansatech Instruments Ltd., King's Lynn, UK). Leaves were adapted to dark conditions for $30 \mathrm{~min}$ using leaf clips. The minimal fluorescence level in the dark-adapted state $\left(\mathrm{F}_{0}\right)$ was measured using a modulate pulse [PPFD $<$ $0.05 \mu$ mol(photon) $\mathrm{m}^{-2} \mathrm{~s}^{-1}$ for $1.8 \mu \mathrm{s}$ ] too small to induce significant physiological changes in the plant (Schreiber et al. 1986). The data recorded were averages taken over a 1.6-s period. Maximal fluorescence in this state $\left(\mathrm{F}_{\mathrm{m}}\right)$ was measured after applying a saturating actinic light pulse of $15,000 \mu \mathrm{mol}$ (photon) $\mathrm{m}^{-2} \mathrm{~s}^{-1}$ for $0.7 \mathrm{~s}$ (BolhàrNordenkampf and Öquist 1993). The value of $F_{m}$ was recorded as the highest average of two consecutive points. Values of the variable fluorescence $\left(F_{v}=F_{m}-F_{0}\right)$ and the maximum quantum efficiency of PSII photochemistry $\left(\mathrm{F}_{\mathrm{v}} / \mathrm{F}_{\mathrm{m}}\right)$ were calculated.

The same leaf section of each plant was used to measure light-adapted parameters. Steady state fluorescence yield $\left(\mathrm{F}_{\mathrm{s}}\right)$ was recorded after adapting plants to ambient light conditions [with full sunlight of 1,150 $\mu \mathrm{mol}\left(\right.$ photon) $\mathrm{m}^{-2} \mathrm{~s}^{-1}$ ]. A saturating actinic light pulse of 
$15,000 \mu \mathrm{mol}\left(\right.$ photon) $\mathrm{m}^{-2} \mathrm{~s}^{-1}$ for $0.7 \mathrm{~s}$ was then used to produce the maximum fluorescence yield $\left(\mathrm{F}_{\mathrm{m}}{ }^{\prime}\right)$ by temporarily inhibiting PSII photochemistry. With both light- and dark-adapted states fluorescence parameters, the following were calculated: quantum efficiency of PSII $\left[\Phi_{\text {PSII }}=\left(\mathrm{F}_{\mathrm{m}}{ }^{\prime}-\mathrm{F}_{\mathrm{s}}\right) / \mathrm{F}_{\mathrm{m}}{ }^{\prime}\right]$, photochemical quenching $\left[\mathrm{q}_{\mathrm{P}}=\right.$ $\left.\left(\mathrm{F}_{\mathrm{m}}{ }^{\prime}-\mathrm{F}_{\mathrm{s}}\right) /\left(\mathrm{F}_{\mathrm{m}}{ }^{\prime}-\mathrm{F}_{0}\right)\right]$, and nonphotochemical quenching $\left[\mathrm{NPQ}=\left(\mathrm{F}_{\mathrm{m}}-\mathrm{F}_{\mathrm{m}}{ }^{\prime}\right) / \mathrm{F}_{\mathrm{m}}{ }^{\prime}\right]$ (Bilger and Björkman 1990).

Photosynthetic pigments of the same leaves used for Chl fluorescence measurements ( $n=4$; 1 leaf per plant) were extracted in October 2009 using $0.1 \mathrm{~g}$ of fresh material in $5 \mathrm{ml}$ of $80 \%$ aqueous acetone. After filtering, $0.5 \mathrm{ml}$ of the suspension was diluted with a further $2 \mathrm{ml}$ of acetone and $\mathrm{Chl} a, \mathrm{Chl} b$, and carotenoids (Car) concentrations were determined with a Hitachi U-2001 spectrophotometer (Hitachi Ltd., Japan) using three wavelengths $(663.2,646.8$, and $470.0 \mathrm{~nm})$. Concentrations of pigments $\left[\mathrm{mg} \mathrm{g}^{-1}(\mathrm{FM})\right]$ were obtained through calculation (Lichtenthaler 1987).

Stomatal density (SD) [number of stomata $\mathrm{mm}^{-2}$ (leaf blade)] was determined for youngest fully developed leaves in December $2009(n=4$; 1 leaf of each plant per treatment). From the abaxial surface of each leaf, a sample was taken using the imprint technique (Meister and Bolhàr-Nordenkampf 2003), three random fields $\left(0.14 \mathrm{~mm}^{2}\right)$ were observed and the number of stomata was counted on each sample using an OLYMPUS BX61 Motorized System Microscope (Horanic and Gardner 1967).

Leaf growth and leaf morphology: Relative leaf growth rate (LGR) was measured for the youngest leaf $(n=4$ plants per treatment; 3 leaves per plant) using an Electronic Digital Caliper in October 2009. Leaves were marked with inert sealant and their length was recorded just after marking them and again 1 week later. LGR was calculated as the net growth in length after 1 week, divided by the initial leaf length (Ewing et al. 1995). Leaf area was calculated applying the ellipse formula after

\section{Results}

Gas exchange: $P_{\mathrm{N}}$ for $\mathrm{T} 3$ was higher than for the other treatments (Fig. 1), showing the $P_{\max }\left[\mathrm{ca} .10 \mu \mathrm{mol}\left(\mathrm{CO}_{2}\right)\right.$ $\left.\mathrm{m}^{-2} \mathrm{~s}^{-1}\right]$ at high light fluxes $\left[1,750 \mu \mathrm{mol}\right.$ (photon) $\left.\mathrm{m}^{-2} \mathrm{~s}^{-1}\right]$ whereas T2 showed the lowest $P_{\max }\left[\mathrm{ca} .6 \mu \mathrm{mol}\left(\mathrm{CO}_{2}\right)\right.$ $\mathrm{m}^{-2} \mathrm{~s}^{-1}$ ]. LSP was much higher for the plants at shade conditions $\left[c a\right.$. 2,000 $\mu$ mol(photon) $\mathrm{m}^{-2} \mathrm{~s}^{-1}$ ] than for those at full sunlight $\left[\mathrm{ca} \cdot 1,125 \mu \mathrm{mol}\right.$ (photon) $\left.\mathrm{m}^{-2} \mathrm{~s}^{-1}\right]$. LCP was the highest for T1 $\left[c a .12 \mu \mathrm{mol}\right.$ (photon) $\mathrm{m}^{-2} \mathrm{~s}^{-1}$ ] and the lowest for $\mathrm{T} 2\left[\mathrm{ca} .4 \mu \mathrm{mol}\right.$ (photon) $\left.\mathrm{m}^{-2} \mathrm{~s}^{-1}\right]$ while the other treatments showed intermediate values [ $\mathrm{ca} .5$ to $8 \mu$ mol(photon) $\mathrm{m}^{-2} \mathrm{~s}^{-1}$ ]. T1 showed the maximum $R_{\mathrm{D}}$ $\left[-0.80 \mu \mathrm{mol}\left(\mathrm{CO}_{2}\right) \mathrm{m}^{-2} \mathrm{~s}^{-1}\right]$ and $\mathrm{T} 2$ the minimum $[-0.35$ $\mu \mathrm{mol}\left(\mathrm{CO}_{2}\right) \mathrm{m}^{-2} \mathrm{~s}^{-1}$ ] with $\mathrm{T} 3$ and $\mathrm{T} 4$ showing values $c a$. -0.5 to $-0.7 \mu \mathrm{mol}\left(\mathrm{CO}_{2}\right) \mathrm{m}^{-2} \mathrm{~s}^{-1}$ (Table 1$)$. recording maximum length and maximum width of adult leaves ( $n=4$ per treatment; 5 leaves per plant).

Leaf area index and specific leaf area: To calculate the leaf area index (LAI) at the end of the experiment we recorded the area covered by each plant and the dry mass of four leaf drilled circular pieces $(1.3 \mathrm{~cm}$ diameter $)$ per plant ( $n=4$ plants). Then to calculate total leaf area and LAI per plant, we used the mass of the circular pieces with a known area and the recorded total leaf dry mass per plant as reported previously. The specific leaf area (SLA) was calculated as the ratio of leaf area to leaf dry mass $\left[\mathrm{cm}^{2} \mathrm{~g}^{-1}\right.$ ] pursuant to Garnier et al. (2001).

Plant morphology, number of inflorescences and biomass allocation: At the end of the experiment, maximum plant height, occupied area (by measuring maximum length and width) and the number of inflorescences were recorded for each plant. Finally plants were removed from the pots, carefully washed and divided into leaves, stems and roots. The components of each plant were dried separately in a forced-air oven $\left(80^{\circ} \mathrm{C}\right.$ for $\left.48 \mathrm{~h}\right)$ and dry mass was recorded.

Statistical analysis: All statistical tests were conducted using SPSS v.17 (Statistic Inc.). The KolmogorovSmirnov test was used to test for data normality and the Levene test for homogeneity of variance. When necessary, dependent variables were transformed using the functions $1 / \mathrm{x}, \ln (\mathrm{x})$ or $\sqrt{\mathrm{x}}$ to achieve requirements of normality. Analysis of variance (ANOVA) was used to detect differences between light treatments and Tukey's Honest Significant Difference (HSD) test was used to detect differences between two treatments only if $F$-test was significant at the 0.05 level of probability. KruskalWallis nonparametric ANOVA was used to compare treatments when normality or homogeneity of variance were not reached after transformations, followed by the Mann-Whitney $U$-test to compare two treatments. Deviations were calculated as standard deviation (SD).

Plants exposed to full sunlight (T1) showed the smallest and almost constant $g_{\mathrm{s}}\left[\mathrm{ca} .90 \mathrm{mmol}\left(\mathrm{H}_{2} \mathrm{O}\right) \mathrm{m}^{-2} \mathrm{~s}^{-1}\right]$. The $g_{\text {s }}$ values for T2 were similar to those for T1 at the lowest light fluxes, increasing to $c a .300 \mathrm{mmol}\left(\mathrm{H}_{2} \mathrm{O}\right)$ $\mathrm{m}^{-2} \mathrm{~s}^{-1}$ at higher PPFD. $g_{\mathrm{s}}$ for T3 and T4 was higher than for T1 and T2, being ca. $300 \mathrm{mmol}\left(\mathrm{H}_{2} \mathrm{O}\right) \mathrm{m}^{-2} \mathrm{~s}^{-1}$ at lower radiations and increasing to $c a .550 \mathrm{mmol}\left(\mathrm{H}_{2} \mathrm{O}\right) \mathrm{m}^{-2} \mathrm{~s}^{-1}$ with PPFD (Fig. 1).

$C_{\mathrm{i}}$ for $\mathrm{T} 1$ ranged from $c a .210-380 \mu \mathrm{mol} \mathrm{mol}{ }^{-1}$, being lower than the $C_{\mathrm{i}}$ for all treatments from $100 \mu \mathrm{mol}$ (photon) $\mathrm{m}^{-2} \mathrm{~s}^{-1}$ onwards. $C_{\mathrm{i}}$ for $\mathrm{T} 2, \mathrm{~T} 3$ and $\mathrm{T} 4$ was ca. $340 \mu \mathrm{mol} \mathrm{mol}^{-1}$. WUE $\mathrm{i}_{\mathrm{i}}$ for $\mathrm{T} 1 \mathrm{was}$ higher (maximum ca. $74 \mathrm{mmol} \mathrm{mol}^{-1}$ ) than for the other treatments ( $c a$. $18 \mathrm{mmol} \mathrm{mol}^{-1}$ ) (Fig. 1). 


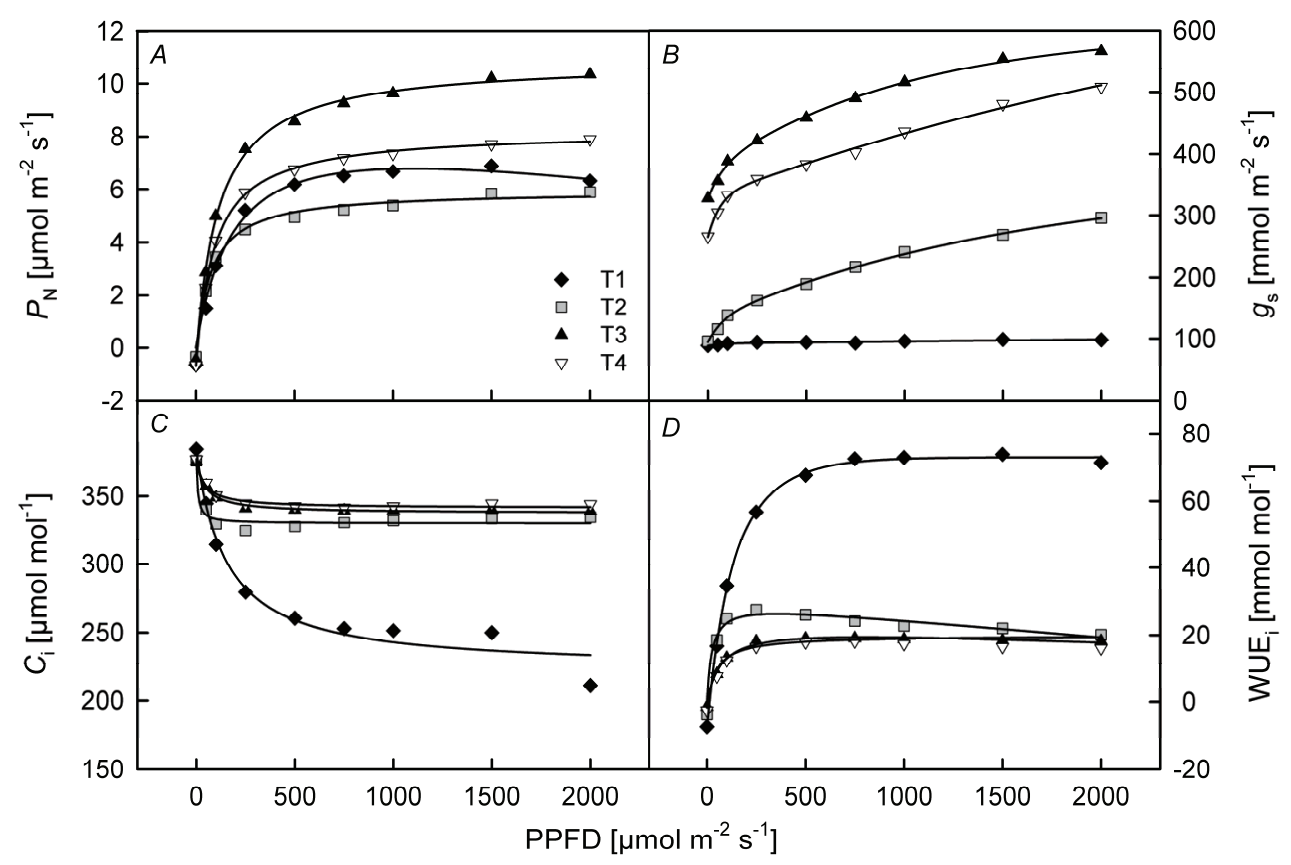

Fig. 1. $A$ : Net photosynthetic rate $\left(P_{\mathrm{N}}\right), B$ : stomatal conductance $\left(g_{\mathrm{s}}\right), C$ : intercellular $\mathrm{CO}_{2}$ concentration $\left(C_{\mathrm{i}}\right)$ and $D$ : intrinsic water-use efficiency $\left(\mathrm{WUE}_{\mathrm{i}}\right.$ ) against photosynthetic photon flux density (PPFD) for Lantana camara in four light treatments (T1: 100\% sunlight; T2: 55\% sunlight; T3: 37\% sunlight; T4: 23\% sunlight). Data are means $(n=2)$.

Table 1. Maximum photosynthetic rate $\left(P_{\max }\right)$, light compensation point $(\mathrm{LCP})$, dark respiration rate $\left(R_{\mathrm{D}}\right)$; and light saturation point (LSP) for Lantana camara in four light treatments (T1 - 100\% sunlight; T2 - 55\% sunlight; T3 - 37\% sunlight; T4 - 23\% sunlight). (mean $\pm \mathrm{SD}, n=2$ light curves per treatment).

\begin{tabular}{lllll}
\hline Variables/Treatments & $\mathrm{T} 1$ & $\mathrm{~T} 2$ & $\mathrm{~T} 3$ & $\mathrm{~T} 4$ \\
\hline$P_{\max }\left[\mu \mathrm{mol}\left(\mathrm{CO}_{2}\right) \mathrm{m}^{-2} \mathrm{~s}^{-1}\right]$ & $6.9 \pm 1.4$ & $5.9 \pm 1.9$ & $10.4 \pm 0.1$ & $7.9 \pm 1.4$ \\
LCP $\left[\mu \mathrm{mol} \mathrm{m} \mathrm{s}^{-1}\right]$ & $11.9 \pm 1.3$ & $3.8 \pm 0.0$ & $5.3 \pm 2.1$ & $8.3 \pm 2.1$ \\
$R_{\mathrm{D}}\left[\mu \mathrm{mol} \mathrm{m}^{-2} \mathrm{~s}^{-1}\right]$ & $-0.8 \pm 0.1$ & $-0.3 \pm 0.0$ & $-0.5 \pm 0.1$ & $-0.7 \pm 0.1$ \\
LSP $\left[\mu \mathrm{mol} \mathrm{m}^{-2} \mathrm{~s}^{-1}\right]$ & $1,125 \pm 530$ & $1,750 \pm 354$ & $1,750 \pm 354$ & $2,000 \pm 0$ \\
\hline
\end{tabular}

Chlorophyll fluorescence: At predawn, $\Phi_{\text {PSII }}(c a .0 .800)$, $\mathrm{q}_{\mathrm{P}}(c a .0 .98), \mathrm{F}_{0}\left(c a .209\right.$ r.u.) and $\mathrm{F}_{\mathrm{v}} / \mathrm{F}_{\mathrm{m}}(c a .0 .850)$ were similar for every treatment. $\mathrm{F}_{\mathrm{m}}, \mathrm{F}_{\mathrm{v}}$ and NPQ for T1 were lower than for the other treatments (Tukey's test, $p<0.01$ ).

$\Phi_{\text {PSII }}$ at midday for $\mathrm{T} 1(0.375 \pm 0.12)$ was lower than for the other treatments (ca. 0.700) (Kruskal-Wallis ANOVA, $\chi^{2}=10.147, p<0.05$; Mann-Whitney U-test, $p<0.05)$. q $\mathrm{P}$ was also lower for $\mathrm{T} 1(0.78 \pm 0.06)$ than for T4 $(0.89 \pm 0.02)$, showing T2 and T3 intermediate values ( $A N O V A, F=4.738, p<0.05$; Tukey's test, $p<0.05$ ). NPQ was much higher for $\mathrm{T} 1(1.61 \pm 0.52)$ than for the other three treatments (ca. 0.29) (Kruskal-Wallis ANOVA, $\chi^{2}=9.551, p<0.05$; Mann-Whitney $U$-test, $\left.p<0.05\right)$. T2, $\mathrm{T} 3$ and $\mathrm{T} 4$ showed a higher $\mathrm{F}_{\mathrm{v}} / \mathrm{F}_{\mathrm{m}}(c a .0 .825)$ than $\mathrm{T} 1$ (ca. 0.788) (Kruskal-Wallis ANOVA, $\chi^{2}=9.288, p<0.05$; Mann-Whitney $U$-test, $p<0.05$ ). Lower values of $\mathrm{F}_{\mathrm{v}} / \mathrm{F}_{\mathrm{m}}$ for $\mathrm{T} 1$ were due to lower $\mathrm{F}_{\mathrm{m}}$ (Tukey's test, $p<0.05$ ) with similar $\mathrm{F}_{0}$ (ca. 200 r.u.; Fig. 2).

Photosynthetic pigments: T1 showed the lowest concen trations of every photosynthetic pigment. T3 had the highest content of $\mathrm{Chl} a\left[1.67 \pm 0.10 \mathrm{mg} \mathrm{g}^{-1}(\mathrm{FM})\right]$ (ANOVA, F = 7.115, $p<0.01$; Tukey's test, $p<0.01$ ) and T2 showed the highest $\mathrm{Chl} b$ content $\left[0.69 \pm 0.12 \mathrm{mg} \mathrm{g}^{-1}\right.$ (FM)] (Kruskal-Wallis, $\chi^{2}=5.333, \quad p<0.05$; MannWhitney $U$-test, $p<0.05)$. Car showed similar values for every shade treatment $\left[\mathrm{ca} .0 .75 \mathrm{mg} \mathrm{g}^{-1}(\mathrm{FM})\right]$ which were all higher than for the full sunlight treatment $[\mathrm{ca} .0 .48 \mathrm{mg}$ $\left.\mathrm{g}^{-1}(\mathrm{FM})\right]$ (ANOVA, $F=4.014, p<0.05 ;$ Tukey's test, $p<0.05)$. Chl $a$ :Chl $b$ ratio varied between 2.42 and 2.98; T2 and T3 showed higher values than T1 (Mann-Whitney $U$-test, $p<0.05)$. Chl $(a+b)$ :Car ratio was higher for T2 $\left[3.19 \pm 0.25 \mathrm{mg} \mathrm{g}^{-1}(\mathrm{FM})\right]$ than for T4 $\left[2.38 \pm 0.49 \mathrm{mg} \mathrm{g}^{-1}\right.$ (FM)], showing T1 and T3 intermediate values (Table 2).

Stomatal density, leaf growth rate and leaf morphology: SD was higher for T1 [283 \pm 23 stomata $\mathrm{mm}^{-2}$ (leaf blade)] than for darker treatments $\left[\mathrm{ca} .170\right.$ stomata $\mathrm{mm}^{-2}$ (leaf blade)]; Kruskal-Wallis ANOVA, $\chi^{2}=9.345, p<0.05$; Mann-Whitney $U$-test, $p<0.05$; Table 2). 


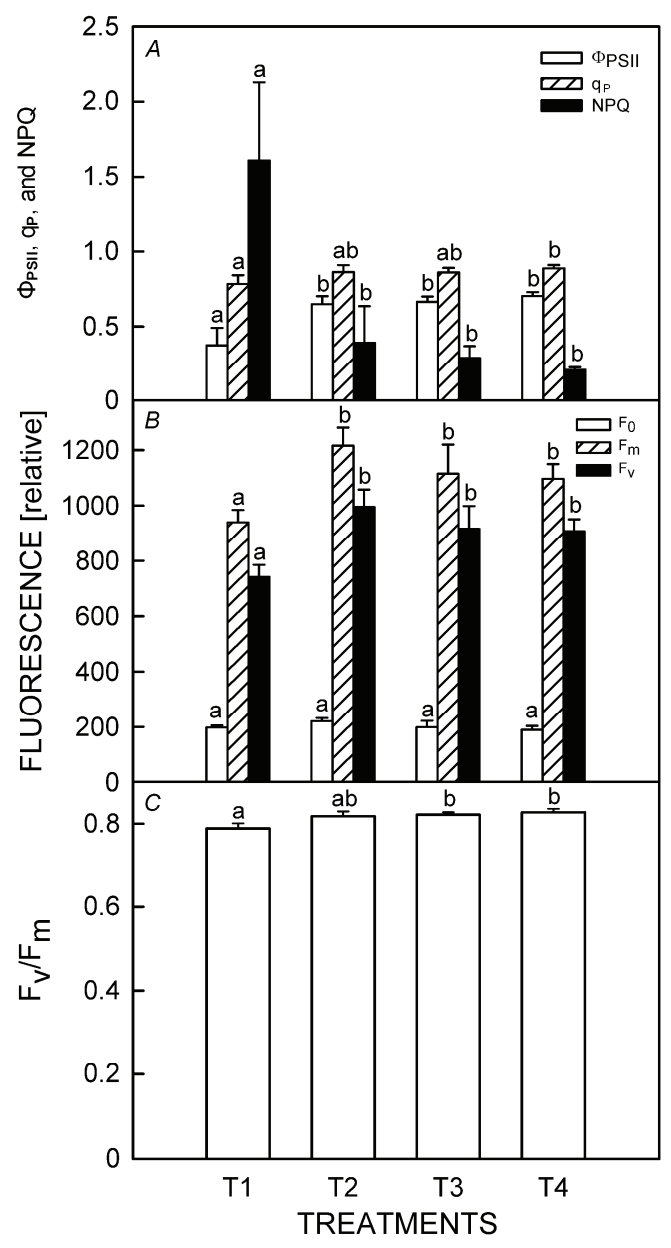

Fig. 2. $A$ : Quantum efficiency of PSII $\left(\Phi_{\mathrm{PSII}}\right)$, photochemical quenching $\left(\mathrm{q}_{\mathrm{P}}\right)$, nonphotochemical quenching (NPQ), $B$ : basal fluorescence $\left(\mathrm{F}_{0}\right)$, maximum fluorescence $\left(\mathrm{F}_{\mathrm{m}}\right)$, variable fluorescence $\left(\mathrm{F}_{\mathrm{v}}\right)$ and $C$ : potential photochemical efficiency $\left(\mathrm{F}_{\mathrm{v}} / \mathrm{F}_{\mathrm{m}}\right)$ for Lantana camara in four light treatments during midday (T1: 100\% sunlight; T2: 55\% sunlight; T3: $37 \%$ sunlight; T4: $23 \%$ sunlight), (mean $\pm \mathrm{SD}, n=4$ ).

\section{Discussion}

This work reports that the invasive species L. camara is able to acclimate to moderately shaded environments, showing high phenotypic plasticity in the form of a wide variety of morphological and physiologically responses, but its reproductive effort was lower at low light fluxes.

As other plant species, morphological acclimation of $L$. camara to low radiations was typified by increasing leaf size, leaf biomass, LAI and plant height, and by decreasing SD and leaf thickness reflected in a higher SLA (Björkman 1981, Poorter and Perez-Soba 2001). Increment of SLA at low light conditions is due to changes in size, shape, and number of leaf mesophyll cells that reduce leaf thickness (Björkman 1981). A higher SD at more illuminated environments has been described previously, being characterized as a xeromorphic leaf feature (Gyorgy 2009). L. camara generally
LGR tended to increase at darker treatments, varying between $c a .0 .85$ and $2.40 \mathrm{~mm}^{-1} \mathrm{wek}^{-1} \mathrm{~mm}^{-1}$. Leaf mean width varied between $4.5 \pm 0.1 \mathrm{~cm}$ and $7.9 \pm 0.2 \mathrm{~cm}$ and leaf mean length between $6.9 \pm 0.3 \mathrm{~cm}$ and $11.8 \pm 0.9 \mathrm{~cm}$. Leaves were larger at darker treatments, changing between $24.3 \pm 3.0 \mathrm{~cm}^{2}$ for $\mathrm{T} 1$ and $74.0 \pm 10.3 \mathrm{~cm}^{2}$ for T4 (ANOVA, $F=15.423, p<0.01$; Tukey's test, $p<0.05$; Table 2).

Leaf area index and specific leaf area: T3 showed a much higher LAI (ca. 21) than T1 and T2 (ca. 8) ( ANOVA, $F=10.240, p<0.01 ;$ Tukey's test, $p<0.05)$. SLA was lower for $\mathrm{T} 1\left(19.67 \pm 3.32 \mathrm{~cm}^{2} \mathrm{~g}^{-1}\right)$ than for shadier treatments (ca. $34 \mathrm{~cm}^{2} \mathrm{~g}^{-1} ; A N O V A, F=12.615, p<0.01$; Tukey's test, $p<0.01$; Table 2 ).

Plant height, cover and number of inflorescences: Plants were taller at darker treatments, varying between $51.0 \pm 6.9 \mathrm{~cm}$ for T1 and $89.7 \pm 3.9 \mathrm{~cm}$ for T3 (KruskalWallis ANOVA, $\chi^{2}=8.886, p<0.05 ;$ Mann-Whitney $U$-test, $p<0.05)$. Individual plant cover was $c a .0 .140 \mathrm{~m}^{2}$, without showing any significant differences between treatments (ANOVA, $p>0.05)$. T1 showed much more inflorescences $\left(127 \pm 34\right.$ inflorescences $\left.\mathrm{m}^{-2}\right)$ than the other three treatments (ca. 20-30 inflorescences $\mathrm{m}^{-2}$; ANOVA, $F=14.658, p<0.01$; Table 2). Finally, the number of fruits per infructescence did not change between treatments, varying between 5 and 15 fruits infructescence ${ }^{-1}$.

Biomass allocation: Stem and root biomass did not vary between treatments (ANOVA, $p>0.05)$. Except T3 showed higher leaf biomass $\left[59.5 \pm 12.9 \mathrm{~g}(\mathrm{DM}) \mathrm{m}^{-2}\right]$ than $\mathrm{T} 1$ and $\mathrm{T} 2\left[c a .33 \mathrm{~g}(\mathrm{DM}) \mathrm{m}^{-2}\right](A N O V A, F=5.164, p<0.05$; Fig. 3). Above-to-belowground biomass and leaves:stems ratios showed no significant differences between light treatments $(A N O V A, p>0.05)$.

grows from 2 to $4 \mathrm{~m}$ high (Auld and Medd 1987, Conn 1992) but to avoid shade conditions it can grow up to $15 \mathrm{~m}$ supported by surrounding vegetation (Swarbrick et al. 1998). This supports our finding of taller plants at shadier environments with larger but thinner stems. L. camara leaves have been reported to be $20-120 \mathrm{~mm}$ long and 15-80 mm wide (Holm et al. 1977, Conn 1992, Munir 1996, Swarbrick et al. 1998, Parsons and Cuthbertson 2001). Our results for plants exposed to full sunlight ranged between those intervals (50-75 mm long and $28-53 \mathrm{~mm}$ wide) but our values for shaded plants (84-137 mm long and 64-94 mm wide) were higher than those recorded previously. Van Oosterhout (2004) recorded changes on L. camara leaf size as a function of moisture availability. Previous studies for different plant species have described increases in foliar size and LAI as 
Table 2. Chlorophyll (Chl) $a, \mathrm{Chl} b$; carotenoids (Car) contents; Chl $a$ :Chl $b$ ratio, Chl $(a+b)$ :Car ratio, stomatal density, relative leaf growth rate, leaf area, plant height, occupied areas per plant, inflorescences, leaf area index and specific leaf area for Lantana camara in four light treatments (T1 - 100\% sunlight; T2 - 55\% sunlight; T3 - 37\% sunlight; T4 - 23\% sunlight). Different letters indicate significant difference between treatments. FM - fresh mass. (mean $\pm \mathrm{SD}, n=4$ ).

\begin{tabular}{|c|c|c|c|c|}
\hline Variables/Treatments & $\mathrm{T} 1$ & $\mathrm{~T} 2$ & T3 & $\mathrm{T} 4$ \\
\hline Chl $a\left[\mathrm{mg} \mathrm{g}^{-1}(\mathrm{FM})\right]$ & $0.93 \pm 0.12^{\mathrm{a}}$ & $1.65 \pm 0.25^{\mathrm{b}}$ & $1.67 \pm 0.10^{\mathrm{b}}$ & $1.38 \pm 0.43^{\mathrm{ab}}$ \\
\hline $\mathrm{Chl} b\left[\mathrm{mg} \mathrm{g}^{-1}(\mathrm{FM})\right]$ & $0.32 \pm 0.06^{\mathrm{a}}$ & $0.69 \pm 0.12^{b}$ & $0.67 \pm 0.05^{\mathrm{b}}$ & $0.41 \pm 0.27^{\mathrm{ab}}$ \\
\hline $\operatorname{Car}\left[\mathrm{mg} \mathrm{g}^{-1}(\mathrm{FM})\right]$ & $0.48 \pm 0.05^{\mathrm{a}}$ & $0.74 \pm 0.12^{\mathrm{b}}$ & $0.77 \pm 0.07^{\mathrm{b}}$ & $0.74 \pm 0.10^{\mathrm{b}}$ \\
\hline Chl $a$ :Chl $b$ & $2.98 \pm 0.35^{\mathrm{a}}$ & $2.42 \pm 0.06^{\mathrm{b}}$ & $2.50 \pm 0.04^{\mathrm{b}}$ & $2.55 \pm 0.04^{\mathrm{ab}}$ \\
\hline $\mathrm{Chl}(a+b): \mathrm{Car}$ & $2.62 \pm 0.41^{\mathrm{ab}}$ & $3.19 \pm 0.25^{\mathrm{a}}$ & $3.07 \pm 0.31^{\mathrm{ab}}$ & $2.38 \pm 0.49^{\mathrm{b}}$ \\
\hline Stomatal density [stomata $\mathrm{mm}^{-2}$ ] & $283 \pm 23^{\mathrm{a}}$ & $197 \pm 42^{\mathrm{ab}}$ & $165 \pm 7^{\mathrm{b}}$ & $181 \pm 25^{\mathrm{b}}$ \\
\hline Leaf growth rate $\left[\mathrm{mm}^{2}\right.$ week $\left.^{-1} \mathrm{~mm}^{-1}\right]$ & $0.85 \pm 0.29^{\mathrm{a}}$ & $1.25 \pm 0.69^{\mathrm{a}}$ & $2.33 \pm 1.44^{\mathrm{a}}$ & $2.39 \pm 0.62^{\mathrm{a}}$ \\
\hline Leaf area $\left[\mathrm{cm}^{2}\right]$ & $24.3 \pm 3.0^{\mathrm{a}}$ & $44.1 \pm 11.6^{\mathrm{ac}}$ & $66.5 \pm 16.7^{\mathrm{bc}}$ & $74.0 \pm 10.3^{\mathrm{b}}$ \\
\hline Plant height $[\mathrm{cm}]$ & $51.0 \pm 6.9^{\mathrm{a}}$ & $83.3 \pm 14.2^{\mathrm{ab}}$ & $89.8 \pm 3.9^{\mathrm{b}}$ & $85.0 \pm 10.4^{\mathrm{b}}$ \\
\hline Occupied area $\left[\mathrm{m}^{2}\right]$ & $0.15 \pm 0.07^{\mathrm{a}}$ & $0.15 \pm 0.03^{\mathrm{a}}$ & $0.14 \pm 0.03^{\mathrm{a}}$ & $0.14 \pm 0.06^{\mathrm{a}}$ \\
\hline Inflorescences [inflorescences $\mathrm{m}^{-2}$ ] & $127 \pm 34^{\mathrm{a}}$ & $33 \pm 33^{\mathrm{b}}$ & $23 \pm 8^{\mathrm{b}}$ & $23 \pm 19^{\mathrm{b}}$ \\
\hline Leaf area index $\left[\mathrm{cm}^{2} \mathrm{~g}^{-1}\right]$ & $6.4 \pm 3.4^{\mathrm{a}}$ & $10.4 \pm 2.0^{\mathrm{a}}$ & $21.4 \pm 6.0^{\mathrm{b}}$ & $14.6 \pm 3.6^{\mathrm{ab}}$ \\
\hline Specific leaf area $\left[\mathrm{cm}^{2} \mathrm{~g}^{-1}\right]$ & $19.7 \pm 3.3^{\mathrm{a}}$ & $34.0 \pm 5.1^{\mathrm{b}}$ & $38.5 \pm 4.9^{b}$ & $32.6 \pm 4.5^{\mathrm{b}}$ \\
\hline
\end{tabular}

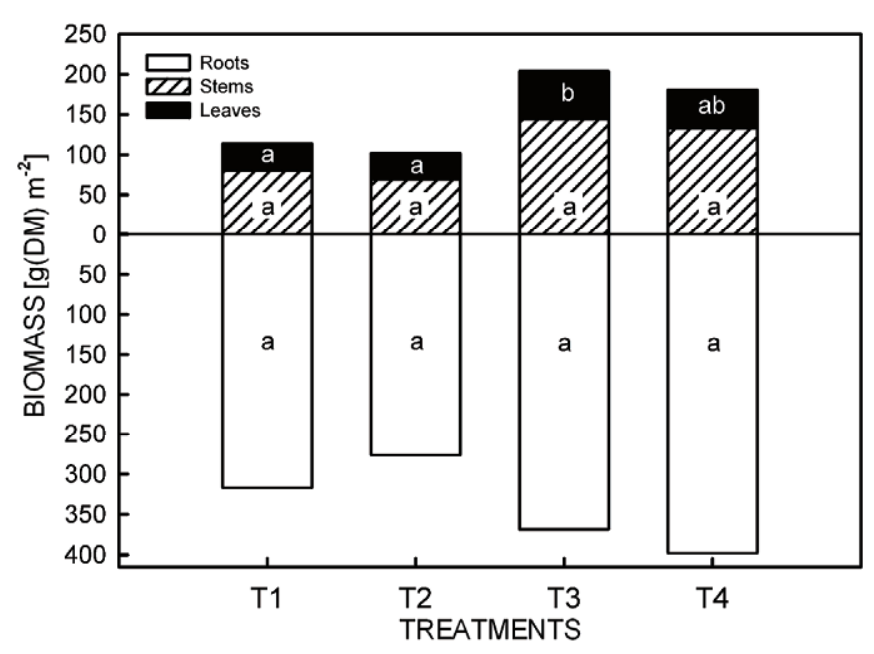

responses to shady conditions (Lichtenthaler et al. 1981, Meziane and Shipley 2001, McAlpine and Jesson 2007).

Above-to-belowground biomass and leaf-to-stem biomass ratios were similar across all light environments. This is not in keeping with optimal partitioning models that predict that some plants optimise growth under different environmental conditions by shifting biomass allocation among tissue types to maximise the capture of limiting resources (McAlpine and Jesson 2007). Thus, L. camara seemed to respond to lower radiation levels by changing its growth form rather than by modifying its biomass allocation pattern. Only foliar biomass in conditions of moderate shade was higher than for plants growing at full sunlight. Plants at full sunlight produced a higher number of inflorescences than the shading treatments as reported in other studies (Hampson et al. 1996, Matsoukis et al. 2001). High temperatures and especially high radiations act as induction stimuli for flowering (Vasconcelos et al. 2009). Our results pointed to the existence of an allocation trade-off among
Fig. 3. Biomass allocation in roots, stems and roots $\left[\mathrm{g}(\mathrm{DM}) \mathrm{m}^{-2}\right]$ for Lantana camara in four light treatments (T1 - 100\% sunlight; T2 - 55\% sunlight; T3 - 37\% sunlight; T4 - 23\% sunlight). Different letters indicate significant difference between treatments. DM - dry mass. Data are means $(n=4)$.

vegetative growth and sexual reproduction for L. camara, capable of producing relatively large and numerous berries, as has been reported for other species (e.g. Thompson and Eckert 2004, Zunzunegui et al. 2006).

On the other hand, L. camara physiological acclimation to low radiation levels was shown as higher $\Phi_{\mathrm{PSII}}, \mathrm{q}_{\mathrm{P}}$, and $F_{v} / F_{m}$ reflecting higher efficiency of PSII (BolhàrNordenkampf and Öquist 1993). The decrease in $F_{v} / F_{m}$ at higher radiation levels was due to lower $F_{m}$ values with similar $\mathrm{F}_{0}$, reflecting deactivation of PSII reaction centres at high light (Maxwell and Johnson 2000).

In addition, plants exposed to shadier conditions showed lower NPQ without a clear relationship with $\mathrm{Chl}(a+b) / \mathrm{Car}$ ratio, which indicates that the xanthophyll cycle seemed to play an important role in L. camara NPQ; this was also supported by the large differences between predawn and midday NPQ recorded for plants exposed to full sunlight (Szabo et al. 2005). Moreover, $\mathrm{Chl}$ concentration increased at lower light fluxes as an acclimation response to increase radiation absorption (Turnbull 1991). In contrast, a reduction in Chl 
concentration at higher radiation levels can be attributed to a photoprotective response against adverse conditions, by reducing the leaf photon absorption capacity, thus preventing over-excitation of photosynthesis (Anderson et al. 1992), as reported for invasive L. camara subjected to extreme drought at Galapagos Islands (Castillo et al. 2007). As a result of the lower concentration of photosynthetic pigments, L. camara plants that grow at full sunlight showed a faster saturation of photosynthesis with light and a consequently lower $\mathrm{q}_{\mathrm{P}}$ and light saturation point. Photoprotection mechanisms allowed L. camara to avoid permanent photodamages as reflected in similar $\Phi_{\text {PSII }}, \mathrm{q}_{\mathrm{P}}$, and $\mathrm{F}_{\mathrm{v}} / \mathrm{F}_{\mathrm{m}}$ for every light treatment at predawn.

The capacity of $L$. camara to acclimate to shady environments was also shown as higher $P_{\mathrm{N}}$, which could be related to very different responses such as a highly efficient PSII and high Chl concentrations. Nevertheless, $P_{\mathrm{N}}$ recorded for L. camara was lower than those reported previously for sun leaves $\left[10-15 \mu \mathrm{mol}\left(\mathrm{CO}_{2}\right) \mathrm{m}^{-2} \mathrm{~s}^{-1}\right.$ ] following Loach (1967) and Larcher (1995), except for plants exposed to $37 \%$ of full sunlight. These plants showed the highest $P_{\mathrm{N}}$ coinciding with the highest $g_{\mathrm{s}}$. In contrast, L. camara plants exposed to full sunlight showed the lowest $g_{\mathrm{s}}\left[\mathrm{ca} .100 \mathrm{mmol}\left(\mathrm{H}_{2} \mathrm{O}\right) \mathrm{m}^{-2} \mathrm{~s}^{-1}\right]$ even with the highest stomatal density, since stomata closure is regulated by radiation level (Broadman 1977, Smith 1981). The low values of $g_{\mathrm{s}}$ at full sunlight did not limit $P_{\mathrm{N}}\left(C_{\mathrm{i}}\right.$ dropped just to $\left.c a .250 \mu \mathrm{mol} \mathrm{mol}{ }^{-1}\right)$ in relation to plants at $55 \%$ of full sunlight with higher $g_{\mathrm{s}}$. As a result, L. camara at full sunlight showed much higher $\mathrm{WUE}_{\mathrm{i}}$ than those exposed to lower radiation levels.

Similar to previous studies of other shade-tolerant species, this plant adjusted physiologically to shading by lower light compensation points and dark respiration rates (Sims and Pearcy 1991, Midgley et al. 1992, Hamerlynck and Knapp 1994, Groninger et al. 1996, Olsen et al. 2002, Aleric and Kirkman 2005), being typified as physiological acclimation to low-light environments (Broadman 1977, Smith 1981). $P_{\max }$ increased with increasing light treatment up to intermediate light levels (37\% of full sunlight), followed by a decline in $P_{\max }$ at full sunlight (Aleric and Kirkman 2005).

L. camara behaves as a facultative shade-tolerant plant, being able to grow on moderately sheltered environments. This result agrees with our field observations of invasive populations in Galapagos Islands and Southwest Iberian Peninsula that are able to colonize

\section{References}

Aleric, K.M., Kirkman, L.K.: Growth and photosynthetic responses of the federally endangered shrub, Lindera melissifolia (Lauraceae), to varied light environments. - Am. J. Bot. 92: 682-689, 2005.

Anderson, J.V., Chevone, B.I., Hess, J.L. Seasonal variation in the antioxidant system of eastern white pine needles. Evidence for thermal dependence. - Plant. Physiol. 98: 501- unaltered forests. Thus, L. camara seems to be capable of invading both open and moderately shaded habitats as are many shade-tolerant invaders (Martin et al. 2009) and it must be able to tolerate considerable self-shading in order thrive in dense thickets of its own growth.

Phenotypic plasticity would be particularly advantageous for L. camara in disturbed environments where light conditions are highly variable. The degree of phenotypic plasticity has been identified as one of the factors that can be used to predict the plant's invasiveness (Ren and Zang 2009). In fact, phenotypic plasticity of some exotic species grown in different light environments has been found to be greater than for co-occurring native species (Pattison et al. 1998, Schweitzer and Larson 1999, Zheng et al. 2009). Moreover, invasive populations showed a higher or similar phenotypic plasticity than the same species in their native populations (Bossdorf et al. 2005). Pattison et al. (1998) showed that invasive species in Hawaii have a higher $P_{\max }$ than native species exposed to contrasted radiation levels. According to Pattison et al. (1998) and Zheng et al. (2009), with a decrease of $c a$. $90 \%$ of full sunlight, plant traits such as LCP, $P_{\max }$, relative growth rate and leaf area decreased between $c a$. $50-85 \%$ in invasive species and between $c a .45-90 \%$ in native species. In contrast, $L$. camara showed positive responses by maintaining or increasing between $30-67 \%$ those variables following a radiation decrease of $77 \%$ of full sunlight. Zheng et al. (2009) showed an increase of SLA of $c a$. $55 \%$ for invasive and of $50 \%$ for native species of Eupatorium with $77 \%$ of full sunlight while that increment for L. camara was $49 \%$ with the same shade treatment.

In view of our results, however L. camara is able to grow in moderately sheltered habitats, control efforts in patchy environments should be directed first and mainly against individuals invading open areas, especially prior to seed production. This is where the progress of its invasions would be much faster, being able to produce several thousand seeds per square meter every year (Sharma et al. 2005). Since L. camara shows a high phenotypic plasticity to light changes and positive responses to intermediated light fluxes, its invasion could be limited in very shady habitats such as some wellconserved forests where poor development has been reported (Thakur et al. 1992, Fensham et al. 1994, Gentle and Duggin 1997).

508, 1992.

Auld, B.A., Medd, R.W.: Weeds. An Illustrated Botanical Guide to the Weeds of Australia. - Inkata Press, Melbourne 1987.

Bazzaz, F.A., Chiariello, N.R., Coley, P.D., Pitelka, L.F.: Allocating resources to reproduction and defense. BioScience 37: 58-67, 1987. 
Bilger, W., Björkman, O.: Role of the xanthophyll cycle in photoprotection elucidated by measurements of light-induced absorbance changes, fluorescence and photosynthesis in Hedera canariensis. - Photosynth. Res. 25: 173-185, 1990.

Björkman, O.: Responses to different quantum flux densities. In: Lange, O.L., Nobel, P.S., Osmond, C.B., Ziegler, H. (ed.): Plant Physiological Ecology. I. Pp. 57-107. Springer-Verlag, Berlin - Heidelberg - New York 1981.

Boardman, N.K.: Comparative photosynthesis of sun and shade plants. - Annu. Rev. Plant Physiol. 28: 355-377, 1977.

Bolhàr-Nordenkampf, H.R., Öquist, G.: Chlorophyll fluorescence as a tool in photosynthesis research. - In: Hall, D.O., Scurlock, J.M.O., Bolhàr-Nordenkampf, H.R., Leegoog, R.C., Long, S.P. (ed.): Photosynthesis and Production in a Changing Environment: A Field and Laboratory Manual. Pp. 193-206. Chapman \& Hall, London - Glasgow - New York Tokyo - Melbourne - Madras 1993.

Bossdorf, O., Auge, H., Lafuma, L., Rogers. W.E., Siemann, E., Prati, D.: Phenotypic and genetic differentiation between native and introduced plant populations. - Oecologia 144: 1-11, 2005.

Castillo, J.M., Leira-Doce, P., Carrión-Tacuri, J., et al.: Contrasting strategies to cope with drought by invasive and endemic species of Lantana in Galapagos. - Biodivers. Conserv. 16: 2123-2136, 2007.

Chartier, P., Prioul, J.L.: The effects of irradiance, carbon dioxide and oxygen on the net photosynthetic rate of the leaf: A mechanistic model. - Photosynthetica 10: 20-24, 1976.

Conn, B.J.: Verbenaceae. - In: Harden, G.J. (ed.): Flora of New South Wales. Pp. 611-618. New South Wales Univ. Press, Kensington 1992.

Daehler, C.C.: Performance comparisons of co-occurring native and alien invasive plants: Implications for conservation and restoration. - Annu. Rev. Ecol. Evolut. Syst. 34: 183-211, 2003.

Dawson, W., Burslem, D.F.R.P., Hulme, P.E.: Factors explaining alien plant invasion success in a tropical ecosystem differ at each stage of invasion. - J. Ecol. 97: 657-665, 2009.

Day, M.D., Wiley, C.J., Playford, J., Zalucki, M.P.: Lantana Current Management Status and Future Prospects. - Aust. Centre Int. Agr. Res., Canberra 2003.

Ewing, K., McKee, K., Mendelssohn, I., Hester, M.: A comparison of indicators of sublethal salinity stress in the salt marsh grass, Spartina patens (Ait.) Muhl. - Aquat. Bot. 52: 59-74, 1995.

Fensham, R.J., Fairfax, R.J., Cannell, R.J.: The invasion of Lantana camara L. in Forty-Mile-Scrub National Park, North Queensland. - Aust. J. Ecol. 19: 297-305, 1994.

Garnier, E., Shipley, B., Roumet, C., Laurent, G.: A standardized protocol for the determination of specific leaf area and leaf dry matter content. - Funct. Ecol. 15: 688-695, 2001.

Gentle, C.B., Duggin, J.A.: Lantana camara L. invasions in dry rainforest - open forest ecotones: The role of disturbances associated with fire and cattle grazing. - Aust. J. Ecol. 22: 298-306, 1997.

Givnish, T.J.: Comparative studies of leaf form: assessing the relative roles of selective pressures and phylogenetic constraints. - New Phytol. 106: 131-160, 1987.

Givnish, T.J.: Adaptation to sun and shade: A whole-plant perspective. - Aust. J. Plant Physiol. 15: 63-92, 1988.

Groninger, J.W., Seiler, J.R., Peterson, J.A., Kreh, R.E.: Growth and photosynthetic responses of four Virginia Piedmont tree species to shade. - Tree Physiol. 16: 773-778, 1996.
György, É.: Anatomic adaptive strategies of some Cormophytes with individuals growing in light and shade conditions. - Not. Bot. Hort. Agrobot. Cluj-Napoca 37: 33-39, 2009.

Hamerlynck, E.P., Knapp, A.K.: Leaf-level responses to light and temperature in two co-occurring Quercus (Fagaceae) species: implications for tree distribution patterns. - Forest Ecol. Manage. 68: 149-159, 1994.

Hampson, C.R., Azarenko, A.N., Potter, J.R.: Photosynthetic rate, flowering and yield component alteration in hazelnut in response to different light environments. - J. Amer. Soc. Hort. Sci. 121: 1103-1111, 1996.

Holm, L.G., Plucknett, D.L., Pancho, J.V., Herberger, J.P.: Lantana camara L. (Verbenaceae, Verbena Family). - In: Herberger, J.P. (ed.): The World's Worst Weeds. Pp. 299302. Univ. Hawaii Press, Honolulu 1977.

Horanic, G.E., Gardner, F.E.: An improved method of making epidermal imprints. - Bot. Gaz. 128: 144-150, 1967.

Lambrinos, J.G.: How interactions between ecology and evolution influence contemporary invasion dynamics. Ecology 85: 2061-2070, 2004.

Larcher, W.: Physiological Plant Ecology: Ecophysiology and Stress Physiology of Functional Groups. - Springer-Verlag, Berlin - New York 1995.

Lichtenthaler, H.K., Buschmann, C., Döll, M., Fietz, H.-J., Bach, T., Kozel, U., Meier, D., Rahmsdorf, U.: Photosynthetic activity, chloroplast ultrastructure, and leaf characteristics of high-light and low-light plants and of sun and shade leaves. Photosynth. Res. 2: 115-141, 1981.

Lichtenthaler, H.K.: Chlorophylls and carotenoids: pigments of photosynthetic biomembranes. - Methods Enzymol. 148: 350$382,1987$.

Loach, K.: Shade tolerance in tree seedlings. I. Leaf photosynthesis and respiration in plants raised under artificial shade. - New Phytol. 66: 607-621, 1967.

Mack, R.N.: Predicting the identity and fate of plant invaders: Emergent and emerging approaches. - Biol. Cons. 78: 107121, 1996.

Martin, P.H., Canhan, C.D., Marks, P.L.: Why forests appear resistant to exotic plant invasions: intentional introductions, stand dynamics, and the role of shade tolerance. - Front. Ecol. Environ. 7: 142-149, 2009.

Martínez-Ferri, E., Manrique, E., Valladares, F., Balaguer, L.: Winter photoinhibition in the field involves different processes in four co-occurring Mediterranean tree species. Tree Physiol. 24: 981-990, 2004.

Matsoukis, A.S., Chronopoulou-Sereli, A., Dimopoulos, I.D., Kamoutsis, A.: Response of Lantana camara subsp. camara to paclobutrazol and shading. - Can. J. Plant Sci. 81: 761-764, 2001.

Maxwell, K., Johnson, G.N.: Chlorophyll fluorescence - a practical guide. - J. Exp. Bot. 51: 659-668, 2000.

McAlpine, K.G. Jesson, L.K.: Biomass allocation, shade tolerance and seedling survival of the invasive species Berberis darwinii (Darwin's barberry). - New Zeal. J. Ecol. 31: 1-12, 2007.

Meister, M., Bolhàr-Nordenkampf, H.: Stomata Imprints: A new and quick method to count stomata and epidermis cells. In: Reigosa Roger, M.J.: Handbook of Plant Ecophysiology Techniques. Pp. 235-250. - Kluwer Academic Publ., Dordrecht 2003.

Meziane, D., Shipley, B.: Direct and indirect relationships between specific leaf area, leaf nitrogen, and leaf gas 
exchange: Effects of irradiance and nutrient supply. - Ann. Bot. 88: 915-927, 2001.

Midgley, G.F., Rutherford, M.C., Davis, G.W., Bösenberg, J. de W.: Photosynthetic responses of heliophilous Rhus species to environmental modification of invasive shrubs. - Func. Ecol. 6: 334-345, 1992.

Moutinho-Pereira, J.M., Correia, C.M., Gonçalves, B.M., Bacelar. E.A., Torres-Pereira, J.M.: Leaf gas exchange and water relations of grapevines grown in three different conditions. - Photosynthetica 42: 81-86, 2004.

Munir, A.A.: A taxonomic review of Lantana camara $\mathrm{L}$. and $L$. Montevidensis (Spreng.) Briq. (Verbenaceae) in Australia. - J. Adel. Bot. Gard. 17: 1-27, 1996.

Muthuchelian, K., Paliwal, K., Gnanam, A.: Influence of shading on net photosynthetic and transpiration rates, stomatal diffusive resistance, nitrate reductase and biomass productivity of a woody legume tree species (Erythrina variegata Lam.). - Proc. Indian Acad. Sci. (Plant Science) 99: 539-546, 1989.

Olsen, R.T., Ruter, J.M., Rieger, M.W.: Photosynthetic responses of container-grown Illicium L. taxa to sun and shade. - J. Amer. Soc. Hort. Sci. 127: 919-924, 2002.

Parsons, W.T., Cuthbertson, E.G.: Noxious Weeds of Australia. $2^{\text {nd }}$ Ed. Pp. 698 - CSIRO Publishing, Melbourne 2001.

Pattison, R.R., Goldstein, G., Ares, A.: Growth, biomass allocation and photosynthesis of invasive and native Hawaiian rainforest species. - Oecologia 117: 449-459, 1998.

Poorter, H., Pérez-Soba, M.: The growth response of plants to elevated $\mathrm{CO}_{2}$ under non-optimal environmental conditions. Oecologia 129: 1-20, 2001.

Ren, M.X., Zang, Q.G.: The relative generality of plant invasion mechanisms and predicting future invasive plants. - Weed Res. 49: 449-460, 2009.

Sage, R.F., McKown, A.D.: Is $\mathrm{C}_{4}$ photosynthesis less phenotypically plastic than $\mathrm{C}_{3}$ photosynthesis? - J. Exp. Bot. 57: 303-317, 2006.

Schreiber, U., Schliwa, W., Bilger, U.: Continuous recording of photochemical and nonphotochemical chlorophyll fluorescence quenching with a new type of modulation fluorometer. - Photosynth. Res. 10: 51-62, 1986.

Schweitzer, J.A., Larson, K.C.: Greater morphological plasticity of exotic honeysuckle species may make them better invaders than native species. - J. Torrey Bot. Soc. 126: 15-23, 1999.

Sharma, G.P., Raghubanshi, A.S., Singh, J.S.: Lantana invasion: An overview. - Weed Biol. Manage. 5: 157-165, 2005.
Sharma, O.P., Makkar, H.P.S., Dawra, R.K.: A Review of the noxius plant Lantana camara. - Toxicon 26: 975-987, 1988.

Sims, D.A., Pearcy, R.W.: Photosynthesis and respiration in Alocasia macrorrhiza following transfers to high and low light. - Oecologia 86: 447-453, 1991.

Smith, H.: Adaptation to shade. - In Johnson, C.B. (ed.): Physiological Processes Limiting Plant Productivity. Pp. 159173. Butterworths, London - Boston - Sydney - Wellington Durban - Toronto 1981.

Swarbrick, J.T., Willson, B.W., Hannan-Jones, M.A.: Lantana camara L. - In: Panetta, F.D., Groves R.H., Shepherd, R.C.H. (ed.): The Biology of Australian Weeds, Pp. 119-136. Richardson, Melbourne, 1998.

Szabo, I., Bergantino, E., Giacometti, G.M.: Light and oxygenic photosynthesis: energy dissipation as a protection mechanism against photo-oxidation. - EMBO Rep. 6: 629-634, 2005.

Thakur, M.L., Ahma, M., Thakur, R.K.: Lantana weed (Lantana camara var. aculeata Linn) and its possible management through natural insect pests in India. - Indian Forester 118: 466-488, 1992.

Thompson, F.L., Eckert, C.G.: Trade-offs between sexual and clonal reproduction in an aquatic plant: experimental manipulations vs phenotypic correlations. - J. Evol. Biol. 17: 581-592, 2004.

Turnbull, M.H.: The effect of light quantity and quality during development on the photosynthetic characteristics of six Australian rainforest tree species. - Oecologia 87: 110-117, 1991.

van Oosterhout, E.: Lantana Control Manual. Current Management and Control Options for Lantana (Lantana camara) in Australia. Queensland Department of Natural Resources. Mines and Energy Publisher, Brisbane 2004.

Vasconcelos, M.C., Greven, M., Winefield, C.S., Trought, M.C.T., Raw, V.: The Flowering Process of Vitis vinifera: A Review. - Amer. J. Enol. Viticult. 60: 411-434, 2009.

von Caemmerer, S., Farquhar, G.D.: Some relationships between the biochemistry of photosynthesis and the gas exchange of leaves. - Planta 153: 376-387, 1981.

Zheng, Y.-L., Feng, Y.-L., Liu, W.-X., Liao, Z.-Y.: Growth, biomass allocation, morphology, and photosynthesis of invasive Eupatorium adenophorum and its native congeners grown at four irradiances. - Plant Ecol. 203: 263-271, 2009.

Zunzunegui, M., Diaz Barradas, M.C., Clavijo, A., Alvarez Cansino, L., Ain Lhout, F., García Novo, F.: Ecophysiology, growth timing and reproductive effort of three sexual forms of Corema album (Empetraceae). - Plant Ecol. 183: 35-46, 2006. 